\title{
TRADISI AKADEMIK PESANTREN: \\ PERUBAHAN SISTEM MANAJEMAN DARI TRADISIONAL KE MODERN
}

\author{
AHMAD SHIDDIQ \\ STKIP PGRI Sumenep \\ Pena221@yahoo.co.id
}

\begin{abstract}
Pesantren as education institute can plant knowledge of Indonesia human being, exhaustively. Science tradition of pesantren with a number of its peripheral, giving nuance differ from tradition outside pesantren. strong Science tradition in pesantren give stock [at] santri later after expressed to pass (mampu) master buku Turn yellow ( Classicly), later; then get diploma from a kiai. tradition of Akademik santri in pesantren, representing one form process complete study, which can present one grad buttonhole of pesantren eclectic have, matured personality [to], and high capable in engineer social. Instruction of bukus turn yellow the by kiai santri [done/conducted] in form of sorogan, or bandungan of weton, deliberation class and halaqah. While education system in PP Annuqayah that is system of shalaf (tradisional) of khalaf (Modern, klasikal). this Shalaf System in maisonette/bording of pesantren [in] Annuqayah used in maisonette/bording pesantren of itself, good [of] Sorogan, weton, bandungan. system of Khalaf in Maisonette/bording of Pesantren Annuqayah in its growth, there is three applied system in Maisonette/bording of Pesantren that is System of Klasikal, coursess system, practice and education.
\end{abstract}

Abstrak

Pesantren sebagai lembaga pendidikan mampu menyemaikan pengetahuan manusia Indonesia, secara mendalam. Tradisi keilmuan pesantren dengan sejumlah perangkatnya, memberikan nuansa berbeda dengan tradisi di luar pesantren. Tradisi keilmuan yang kuat dalam pesantren memberikan bekal pada santri kelak setelah dinyatakan lulus (mampu) menguasai kitab Kuning (Klasik), kemudian mendapat ijazah dari seorang kiai. Tradisi akademik santri di pesantren, merupakan satu bentuk proses pembelajaran yang tuntas, yang dapat menampilkan satu sosok lulusan pesantren yang berwawasan luas, berkepribadian matang, dan berkemampuan tinggi dalam melakukan rekayasa social. Pengajaran kitab-kitab kuning tersebut oleh santri kiai dilakukan berbentuk sorogan, bandungan atau weton, halaqah dan kelas musyawarah. Sedangkan sistem pendidikan di PP Annuqayah yaitu sistem shalaf (tradisional) dan khalaf (Modern, klasikal). System shalaf ini dalam pondok pesantren di Annuqayah digunakan dalam pondok pesantren itu sendiri, baik Sorogan, weton, bandungan. Sistem khalaf dalam Pondok Pesantren Annuqayah dalam perkembangannya, ada tiga sistem yang diterapkan di Pondok 
Pesantren yaitu Sistem Klasikal, sistem kursus-kursus, pendidikan dan latihan.

\section{Kata Kunci : Tradisi Akademik, Sistem Manajeman, dan Pesantren}

\section{Pendahuluan}

Pesantren merupakan lembaga pendidikan Islam yang berakar dari budaya masyarakat Indonesia ${ }^{1}$. Keberadaan pesantren mengalami pasang-surut dari masa ke masa, mengharuskan bertransformasi dengan dunia luar meski di satu sisi harus mempertahankan tradisi kuat dalam pesantren sendiri. Tentu hal ini merupakan upaya lembaga pendidikan yang sudah lebih ratusan tahun bisa eksis sesuai tuntutan zaman. Ada anggapan Pesantren terkadang dipandang jumud, tidak tertib, terlalu sederhana, tempat penampungan anak-anak nakal, dan tidak terlalu responsif terhadap perkembangan zaman. Tentu penilaian negatif dari luar pesantren ini, secara umum tentu kurang tepat dan juga tidak semuanya salah terhadap penilaian tersebut.

Pesantren sebagai lembaga pendidikan mampu menyemaikan pengetahuan manusia Indonesia, secara mendalam. Tradisi keilmuan pesantren dengan sejumlah perangkatnya, memberikan nuansa berbeda dengan tradisi di luar pesantren. Tradisi keilmuan yang kuat dalam pesantren memberikan bekal pada santri kelak setelah dinyatakan lulus (mampu) menguasai kitab Kuning (Klasik), kemudian mendapat ijazah dari seorang kiai. Untuk mengamalkan ilmunya di tengah-tengah masyarakat. Ada banyak pengalaman yang terasa di pesantren untuk dikembangkan di masyarakat. Untuk itu, terasa penting menjaga tradisi keilmuan di pesantren yang sudah membumi di kalangan santri agar tidak usang, dan mampu menjadi bekal kelak di masyarakat. Tradisi membaca kitab kuning yang menggunakan ilmu alat, seperti leksigokrafi, gramatika, mantiq. Sebagai produk intelektual pesantren, kitab kuning tidak ada pada masa awal perkembangan Nusantara, seperti yang diperkirakan para peneliti bahwa kitab kuning baru abad ke-16 berbahasa Arab dan Jawi. Serta menjadi kurikulum massal di pesantren sekitar abad 18-19 ketika banyak pelajar indonesia belajar di mekkah. ${ }^{2}$

\section{Pesantren Sebuah Gambaran Umum}

Sebagai lembaga pendidikan Islam, pesantren menjadi pusat pendidikan kader ulama dan para mustamik. Istilah pesantren di Nusantra berasal dari kata "santri" yang mendapat kata awal "pe" dan akhiran "an" yang berarti tempat

\footnotetext{
${ }^{1}$ Hanun Asroha, Pelembagaan Pesantren, Asal Usul dan Perkembangan pesantren di Jawa (Jakarta DEPAG RI, 2004) 61-64

2 Affandi Mohtar, Membedah Diskursus Pendidikan Islam,(Ciputat: Kalimah, 2001), 39-40
} 
para santri menuntut ilmu ${ }^{3}$ menurut Johns berasal dari bahasa tamil "sastri" bermakna guru ngaji, dan "shastri" dalam bahasa india mempunyai arti orang yang mempunyai kitab suci agama Hindu menurut pendapat CC. Berg seperti dikutip oleh Zamakhsari Dhofir. ${ }^{4}$ Menurut Robson berasal bahasa Tamil sattiri yang di maksudkan pada arti orang yang tinggal disebuah rumah miskin dan bangunan secara umum.

Dengan ada perbedaan asal kata dan makna pada pendapat para peneliti di atas, tentu mengandung persamaan makna santri itu sendiri. Pendapat pertama yang mengatakan bahwa santri adalah guru ngaji, ini menjadi bagian dari aktivitas santri yang setelah mencari ilmu ajaran agama kemudian memberikan pelajaran ajaran agama pada masyarakat sekitar, dalam hal ini dikenal "guru mengaji". Tentu tidak mengurangi makna pendapat yang kedua, yang menurut Berg, santri mempunyai makna kitab suci atau buku-buku agama, karena santri adalah orang menuntut ilmu agama baik dari kitab suci Islam atau teks-teks agama yang ditulis oleh ulama salaf (terdahulu). Dan pendapat yang ketiga juga mempunyai makna yang terhubung, seperti pendapat Robson bahwa santri adalah orang yang tinggal di rumah miskin, dan ini sesuai dengan kehidupan yang tinggal di asrama yang sangat sederhana dan jauh dari kesan mewah. ${ }^{5}$

Sedangkan Nur Khalis Majdid memberi opsi dua pendapat dalam tulisannya, ia mengatakan bahwa pertama, santri berasal dari kata sastri bahasa sansakerta yang berarti melek huruf, ini menunjukkan bahwa santri adalah kelas literasy bagi orang jawa. Ini disebabkan pengetahuan mereka tentang agama melalui kitab-kitab bertulisan dan berbahasa arab. Kedua, bahwa perkataan santri sesungguhnya berasal dari bahwa Jawa, persisnya dari kata cantrik, yang artinya sesorang yang selalu mengikuti seorang guru ke mana guru ini pergi menetap. ${ }^{6}$

Kemudian definisi pondok pesantren adalah sebuah asrama pendidikan Islam tradisional di mana para siswanya (santri) tinggal bersama di bawah bimbingan sesorang atau lebih guru yang lebih dikenal sebutan kiai.7 Sedangkan menurut pendapat para tokoh Abdurrahman Wahid menyatakan pesantren sebagai tempat santri hidup, ${ }^{8}$ Matsuhu sendiri menberi batasan Pesantren sebagai lembaga pendidikan tradisional Islam untuk mempelajari, memahami, menghayati dan mengamalkan ajaran agama Islam dengan menekankan pentingnya moral keagamaan sebagai pedoman perilaku sehari-hari ${ }^{9}$

Zamakhsari Dhofir, dalam buku Tradisi Pesantren, menggambarkan definisi pesantren sebagai lembaga pendidikan tradisional Islam untuk

\footnotetext{
${ }^{3}$ Hanun Asrohah, Pelembagaan Pesantren, Asal-Usul Pesantren di Jawa. (Jakarta : Depag RI, 2004), 30

4 Zamakhsari Dhofir, Tradisi Pesantren, studi tentang pandangan hidup kiai, (Jakarta : LP3ES, 1994),18

${ }^{5}$ Zamakhsari Dhofir, Tradisi Pesantren, studi tentang pandangan hidup kiai, (Jakarta : LP3ES, 1994). 30

${ }^{6}$ Nur Khalis Madjid, Pola pergaulan dalam pesantren, dalam buku Bilik-Bilik Pesantren, (Jakarta : Dian Rakyat). 21-22

7 Imron Arifin, Kepemimpinan Kiai, Kasus Pondok Pesantren Tebuireng, (Malang : Kalimasahada Press, 1993). 6

8 Abdurahman Wahid, Menggerakkan tradisi, (Yogyakarta: LKIS, 2010), 62

${ }_{9}$ Matsuhu, Dinamika Sistem Pendidikan Pesantren (Jakarta : INIS, 1994), 55
} 
mempelajari, memahami, mengahayati dan mengamalkan ajaran agama dengan menekankan pentingnya moral keagamaan sebagai pedoman perilaku seharihari ${ }^{10}$. Dan Nur Khalis Madjid memberikan tambahan pandangan bahwa pesantren adalah wujud proses wajar perkembangan sistem pendidikan Nasional ${ }^{11}$.

Sudjoko Prasodjo memberikan definisi lain, bahwa pesantren sebagai lembaga pendidikan dan pengajaran agama, umumnya dengan cara nonklasikal di mana seorang kiai atau ustadz mengajarkan ilmu agama Islam kepada santrisantri berdasarkan kitab-kitab yang ditulis dalam bahasa arab oleh ulama abad pertengahan, dan para santri umumnya tinggal di asrama pesantren tersebut. ${ }^{12}$ Dari definisi di atas dapat diambil kesimpulan bahwa pesantren lembaga pendidikan tradisional Islam Indonesia di mana proses belajar dan mengajar tentang agama Islam antara kiai dan santri berlangsung dan asrama (pondok) sebagai tempat tinggal santri serta kitab kuning yang ditulis ulama salaf abad pertengahan sebagai bahan pelajaran dalam bentuk tradisional (wetonan, bandongan, ataupun sorogan) dan atau sistem Madrasah (klasikal).

Sistem pendidikan pesantren adalah totalitas interaksi dari seperangkat unsur-unsur pendidikan yang bekerja sama secara terpadu, dan saling melengkapi satu sama lainnya menuju tercapainya tujuan pendidikan yang telah menjadi cita-cita bersama para pelakunya. Para pelaku pesantren adalah : kiai (pengasuh), ustadz (pembantu kiai dalam mengajar agama), guru (pembantu kiai mengajar ilmu umum), santri (pelajar), dan pengurus (pembantu kiai untuk kepentingan umum pesantren). ${ }^{13}$ Unsur-unsur di atas ini dalam suatu sistem pendidikan disebut unsur-unsur organik, dan sedangkan unsur-unsur Anorganik yaitu : tujuan, filsafat dan tata nilai, kurikulum dan sumber belajar, proses kegiatan belajar-mengajar, penerimaan murid dan tenaga kependidikan, teknologi kependidikan, dana, sarana, evaluasi dan peraturan terkait lainnya didalam mengelola sistem pendidikan. ${ }^{14}$

Pada unsur-unsur sistem pendidikan dikelompokkan pada (1) Actor atau pelaku, Kiai, Ustaz, santri, dan pengurus; (2) Sarana perangkat keras : Masjid, rumah kiai, asrama ustadz, pondok atau asrama santri, gedung sekolah, atau madrasah, tanah untuk olah raga, pertanian atau peternakan, empang, makam, dan lainnya; (3) Saran perangkat lunak: tujuan Kurikulum, Kitab, penilaian, tata tertib, perpustakaan, pusat dokumentasi, penerangan, cara pengajaran (sorongan, bondongan dan halaqoh), keterampilan, pusat pengembangan masyarakat, dan alatalat pendidikan lainnya.

Kelengkapan unsur-unsur system pesantren berbeda satu pesantren dengan pesantren lainnya, ada yang lengkap memiliki unsur-unsur tersebut dan

\footnotetext{
10 Matsuhu, Dinamika Sistem Pendidikan Pesantren (Jakarta : INIS, 1994), 18

11 Matsuhu, Dinamika Sistem Pendidikan Pesantren (Jakarta : INIS, 1994), 3

12 Soedjoko Prasojo, Profil Pesantren (Jakarta : LP3ES, 1978 )

${ }_{13}$ Matsuhu, Dinamika sistem pendidikan pesantren, (Jakarta : INIS, 1994), 6

${ }_{14}$ Matsuhu, Dinamika Sistem Pendidikan Pesantren (Jakarta : INIS, 1994),19
} 
ada yang hanya memiliki sebagian kecil dan tidak lengkap. ${ }^{15}$ Karena dalam penelitian ini selintas meneliti tentang sistem pendidikan pesantren maka peneliti hanya menggambarkan selintas sistem pendidikan pesantren secara umum.

Pesantren mempunyai nilai-nilai yang menjadi landasan para santri untuk melakukan kegiatan sehari-hari. tentu hal ini, tidak lepas dari paham Ahlussunnah Wal-Jama'ah. Paham ini oleh kalangan santri mempunyai konotasi khas dan dilekatkan pada orang-orang pesantren bahkan pada komunitas organisasi Nahdltul Ulama (NU), tapi tidak sedikit yang mengatakan bahwa dirinya bukan NU, ada Muhammadiyah, PERSIS dan lainnya. Paham yang ahlussunnah waljam'ah ini lazim disebut sunni ${ }^{16}$. Diluar sunni ada banyak golongan yakni ; Syiah,17 Khawarij18, Murjiah,19 Jabariyah,20 Qadariyah,21 dan Mu'tazilah" ${ }^{22}$. Tetapi yang terkenal dalam ummat Islam terbagi golongan besar yakni Sunni dan Syiah.

Hal ini terpecah-pecah karena faktor politik pasca Rasullah wafat, dalam penentuan suksesi kepemimpinan. Yang disebut paham ahlusunnah wal jama'ah, dikalangan pesantren sendiri dikenal sangat sederhana yaitu dengan mengatakan sebagai pengikut ajaran al-Asy'ari²3 dan al-Maturidi ${ }^{24}$ dibidang theology (aqidah

${ }^{15}$ Lihat Soedjoko prasodjo, dkk. Profil pesantren, (Jakarta : LP3ES, 1978), Abdurahman Wahid, Bunga Rampai Pesantren, LP3ES, Jakarta, 1982 dan Zamachsyari Dhofier, tradisi Pesantren, (Jakarta: LP3ES, 1982),

${ }_{16}$ Sunni adalah sebuah ungkapan yang digunakan untuk menyebut umat islam yang mempercayai bahwa nabi Muhammad tidak merujuk seseorang tertentu untuk menggantikannya dan menerima kekhalifaan Abu Bakar, Umar Ibnu Khattab, Uthman bin Affan, Ali Bin Abi Thalib bahkan Muawiyah; tetapi berkembang menjadi wacana teologi dan akhirnya dikenal sebagai theology yang dianut oleh mayoritas umat Islam.

17 Syiah adalah sekte umat Islam yang meyakini bahwa nabi Muhammad telah menunjuk Ali bin Abi Thalib dan keturunannya sebagai penggantinya dan imam bagi umat islam.

${ }^{18}$ Khawarij adalah sekte umat Islam yang semula termasuk pengikut Ali bin Abi Thalib yang ikut memerangi Muawiyah yang menolak kekhalifan Ali Bin Abi Thalib menggantikan Uthman Bin Affan. Mereka memisahkan dengan Ali ketika Ali menerima tawaran damai Muawiyah.

19 Murjiah adalah sekte umat islam yang mengajarkan bahwa penghakiman terhadap setiap orang beriman yang melakukan perbuatan dosa besar supaya ditangguhkan, menunggu ketentuan tuhan di hari kemudian.

20 Jabariyah adalah sekte umat islam yang menolak keyakinan akan kebebasan manusia dalam berkehendak dan bertindak.

${ }^{21}$ Qadariyah adalah sekte yang percaya bahwa manusia memiliki kebebasan berkehendak dan bertindak.

$22 \mathrm{Mu}$ 'tazilah merupakan sekte umat Islam yang secara ketat meyakini keesaan dan keadilan tuhan serta percaya bahwa seorang muslim yang melakukan dosa besar akan ditempatkan di antara surge dan neraka. lebih lanjut Lihat W. Montgomery Watt, studi islam Klasik, Studi kritik sejarah, (Yogya : Tiara Wacana, 1999), 47-74

23 Paham ini di sandarkan pada Nama imam yang mempunyai nama lengkap Abu Hasan Ali bin Isma'il bin Abi Basyar bin Ishaq Bin salim bin ismail bin Abdillah bin Musa bin Bilal bin Abi Burdah bin Abi Musa Al-Asy'ari. Lahir di Basrah (Iraq) tahun 260 H $(873$ M) dan wafat tahun $324(935 \mathrm{H})$, pada tempat yang sama.

24 Begitu juga al-maturidi dinisbatkan pada namanya yakni : Muhammad bin Mahammad bin Mahmud bin Mansurn al-Maturidi lahir di samarqan dan wafat pada tahun $333 \mathrm{H}$. 
dan tauhid) dan pengikut empat madhabz dalam bidang Syari'ah dan fiqih.(hukum) ${ }^{25}$.

Di pesantren sendiri paham ini tidak asing, sebab moyoritas pesantren di Indonesia sangat kental paham ahlussunah wal jama'ah, seperti yang dipaparkan oleh Nur khalis Madjid, bahwa dikalangan santri mempelajari rumusan teologi alAsy'ari yang dua puluh sifat yang terkenal, bahkan hafal diluar kepala. ${ }^{26}$

\section{Akar Tradisi Akademik Pendidikan Islam Klasik}

Islam adalah agama pengetahuan. Karenanya Islam mempunyai tradisi akademik yang panjang dalam menemukan bentuk ${ }^{27}$. Ada tiga tahap tradisi skolastik dalam sejarah intelektual Islam. ${ }^{28}$ Pertama, adalah tahap penerjemahan karya-karya yunani kuno ke dalam bahasa Arab. Hal ini dapat dilihat dari perkembangan pembangunan perpustakaan, baik Darul Hikmah, Darul Kutub, sehingga tiap orang bisa mengakses koleksis perpustakaan. Sebagai pintu masuk bagi pemikiran yunani kuno ke tradisi Islam.

Kedua, adalah tahap rasionalisasi pemikiran pemikiran teologi Islam yang mengarah pada peristiwa mihnah. Hal ini konsekwensi dari perkenalan para teolog muslim terhadap pemikiran Yunani kuno baik Aristoteles dan Plato. Demikian ini menjadi penanda pengaruh pemikiran mu'tazilah terhadap pandangan, sikap, dan perilaku khalifah Al-Makmun (813-833 M). Ketiga, tahap kebangkitan dan kemenangan ortodoksi kaum sunni. Ini ditandai dengan terbentuknya empat madzhab dalam hukum Islam. Yakni madzhab Maliki, Hambali, Hanafi, dan Syafi'I. Sebelumnya madzhab bersifat individu dengan jumlah sangat banyak. Hal ini penting di mengingat secara geografis Islam sudah menyebar luas.

Dilihat dari kebebasan akademik pada perguruan tinggi Islam masa lalu, ada dua macam kategori. Kategori pertama, yaitu lembaga pendidikan formal dengan ci ri eksklusif dan kedua, informal dengan cirri bebas. ${ }^{29}$ Kedua kategori diatas, dalam dunia akademik hubungan antara siswa dan guru berlangsung sangat personal. Sehingga memberi keluasaan besar bagi guru-murid untuk menentuk materi danm pemberian ijazah. Dengan demikian, professor (guru) dapat mengukur kwalitas kelayakan keilmuan siswa.

\footnotetext{
${ }^{25}$ Ke empat Imam Madzhab yaitu 1. Madzhab Hanafi, penyusunnya adalah Imam Abu Hanifah anNu'man bin Tsabit al- Kufi, (80-15 H/699-767 M), 2.Madzhab Maliki penyusunnya adalah Malik bin Anas bin Malik Al-Madani (93-179/712-798 M), 3. Madzhab Syafi'I yang menyusun Muhammad bin Idris bin Abbas bin Usman bin syafi' bin saib ibnu 'Abid bin 'Abdi Yazid bin Hasyim bin Muthallib bin Abdi Manaf (150-204 H/767-820 M), 4. Madzhab hambali dengan nama penyusunnya adalah Ahmad Bin Muhammad bin Hambal bin Hilal (164-241 H/780-855 M). dan Lebih lengkapnya lihat Chairul Anam, Pertumbuhan dan perkembangan NU, (Surabaya: Duta Aksara, 2010), 151-174.

26 Nur Khalis Madjid, Bilik-Bilik Pesantren (Jakarta : Dian Rakyat, ) 33 ,

27 Said agil siraj, Tasawwuf Sebagai Kritik Sosial.,

28 Affandi Mohtar, Membedah Diskursus Pendidikan Islam,(Ciputat: Kalimah, 2001), Affandi Mohtar, $85-86$

${ }^{29}$ Affandi Mohtar, Membedah Diskursus Pendidikan Islam,(Ciputat: Kalimah, 2001), Affandi Mohtar, 88
} 


\section{Tradisi Akademik Pesantren Annuqayah; Pergeseran Dari Tradisional Ke Modern}

Pengetahuan pesantren yang dimaksud disini adalah pengetahuan syari'ah yang menjadi bahan pelajaran di pesantren. Menurut Nur Khalis Madjid ada empat pengetahuan yaitu: (1) Fiqh, (2) Tasawwuf, (3) Tauhid, dan (4) ilmu Nahwu-Sharaf. ${ }^{30}$ Sedang Zamakhsari Dhofir, memberikan pandangan melengkapi pandangan di atas yakni ada delapan pengetahuan pesantren (1) Nahwu dan sharraf, (2) fiqh, (3) ushul fiqh, (4) hadist, (5) tafsir, (6) Tauhid. (7) Tasawwuf dan etika, dan (8) Cabang ilmu lainnya seperti tarikh dan balaghah. ${ }^{31}$. Ahmad Baso, tanpa membedakan ilmu agama dan umum dengan mengelompokkan pengetahuan pesantren menjadi empat belas cabang ilmu ${ }^{32}$. Katagori ilmu-ilmu pengetahuan yang merupakan lingkup kutub al- mu'tabarah, (1) Ilmu Ushul (tauhid) dan ilmu kalam, (2). Ilmu fiqh dan ushul fiqh (termasuk hukum dan undang), (3) ilmu tafsir dan ilmu hadist (4). Ilmu tasawwuf dan ilmu etika (Akhlaq), (5) Ilmu bahasa dan tata bahasa (ilmu nahwu, ilmu sharraf, pengetahuan bahasa-bahasa Nusantara dan leksikografi) (6) Ilmu Balaghah dan Ilmu Manthiq, (dan untuk kategori pengetahuan umum) (7) Ilmu pertanian (8) Ilmu Thib (9) Ilmu Astronomi, ilmu falak, dan astronomi, (10). Matematika dan alJabar, (11) ilmu teknik (12). Ilmu bumi, ilmu alam dan ilmu biologi (13) Ilmu syajarah (14) Ilmu-ilmu sosial (ilmu politik, ilmu tata Negara, dan ilmu ekonomi) ${ }^{33}$.

Hanya saja saja Baso membedakan pada ilmu yang mempelajari, ilmu agama lebih banyak dipelajari oleh santri-ulama sedangkan ilmu umum (non agama) banyak dipelajari oleh santri-mustamik. ${ }^{34}$ Dan Martin Van Bruinessen, mengklasifikasi sepuluh dalam bagian berdasarkan kitab yang sering dipakai dikalangan pesantren, (1) Fiqh, (2) Doktrin (Akidah, ushuludin), (3) Tata bahasa arab tradisional, (nahwu Sharraf, balaghah) (4). Kumpulan Hadith (5) Tasawwuf dan Tarekat, (6) akhlak, (7) kumpulan do'a, Wirid, Mujarrabat (10) Qishash alambiya, mauled, manaqib dan sejenisnya ${ }^{35}$.

30 Nur Khalis Madjid, Bilik-Bilik Pesantren (Jakarta : Dian Rakyat, ) 31, rinciannya dalam masingmasing bidang adalah 1 . Fiqh meliputi safinat $\mathrm{u}$ al- shalah, safinat $\mathrm{u}$ al-najah, al-fathul Qarib, Taqrib, fath-u al-mu'in, minhaju al-qawim, Muthma'innah, al-iqna' wathu al-wahhab, 2. Tauhid meliputi Aqidatu al-Awam, Bad-u al amal dan sanusiyah, 3. Tasawwuf. Yaitu : al-nasha'ih u aldiniyah, irsyad $\mathrm{u}$ al-ibad, tanbih $\mathrm{u}$ al-ghafilin, minhajul abidin, al-dawat $\mathrm{u}$ al-tammah, al-hikam, al-risalat $\mathrm{u}$ al-muawanah wa al- muzhaharah, bidayat $\mathrm{u}$ al-hidayah, sedang ke 4 . Ilmu nahwu sharraf yakni : al-maqsud (nadham), Awamil (Nazham), imriti, (Nadzam), al-jurumiyah, kaylani, Mirhat u al-I'rab, al-fiyah (Nadzam), dan Ibnu Aqil.

31 Nur Khalis Madjid, Bilik-Bilik Pesantren (Jakarta : Dian Rakyat), 50

32 Ahmad Baso, Pesantren Studies 2a, Buku II : Kosmopolitanisme Peradaban Kaum Santri di Masa Kolonial, Juz pertama : pesantren, Jaringan pengetahuan dan Karakter Kosmopolitankebangsaannya, (Jakarta : Pustaka afid), 278.

${ }^{33}$ Keempat belas macam ilmu pesantren, dapat lacak secara seksama dalam witkam, inventory, vol. 6, 160-202, dalam teks- teks ulama Banten dalam berbagai versi bahasa, Pingeaud, literature of Java, vol. 2 dan 3 serta Voorhoeve, handlist.

34 Untuk lebih lengkapnya tentang santri mustamik baca Ahmad Baso, Pesantren Studies, 85-131

35Martin van bruinessen, kitab kuning, pesantren dan tarekat, (Yogyakarta : Madianah, 2012), 150 
Pengetahuan tersebut dalam pesantren berbentuk kitab kuning, meski asal usul penyebutan tersebut tidak diketahui pasti. Ada yang berangggapan pada tahun karangan, ada yang membatasi pada madzhab theology, ada yang membatasi pada istilah mu'tabarah, dan sebagainnya. ${ }^{36}$ Martin Van Bruenessen berargumen karena warna kertasnya, tentu hal ini tidak salah, tapi kurang tepat sebab pada kitab-kitab klasik sudah ada yang diterbitkan dengan memakai kertas putih dunia percetakan.

Istilah kitab kuning ialah kitab-kitab yang memiliki cirri-ciri (1) Ditulis oleh ulama-ulama "asing", tetapi secara turun-temurun menjadi referensi yang dipedomani oleh para ulama Indonesia, (2) Ditulis oleh ulama Indonesia sebagai karya tulis yang independen dan (3) Ditulis oleh ulama sebagai komentar atau terjemahan atas kitab karya asing. ${ }^{37}$

Dari defenisi tersebut, dalam tradisi intelektual Islam, khususnya di Timur Tengah, dikenal dua istilah untuk menyebut kategori karya-karya ilmiyah berdasarkan kurun dan format penulisannya. Yang pertama disebut al-kutub alqadimah (kitab-kitab klasik). Kedua, disebut al-kutubul ashriyyah (kitab-kitab modern), dan kedua kategori tersebut mempunyai perbedaan yaitu cara penulisannya yang tidak mengenal pemberhentian, tanda baca (punctuation), dan kesan bahasanya yang berat, klasik dan tanpa syakl (fathah, dlammah, dan kasrah). Dalam pesantren biasa disebut kitab gundul. Disamping itu, kini perbedaan dari dua kategori adalah terletak pada isi, sistematika, metodelogi, bahasan dan pengarangnya. 38

Kemudian Dalam pesantren, Tradisi akademik santri di pesantren, merupakan satu bentuk proses pembelajaran yang tuntas, yang dapat menampilkan satu sosok lulusan pesantren yang berwawasan luas, berkepribadian matang, dan berkemampuan tinggi dalam melakukan rekayasa social. ${ }^{39}$ Pengajaran kitab-kitab kuning tersebut oleh santri kiai dilakukan berbentuk sorogan, bandungan atau weton, halaqah dan kelas musyawarah. Sorogan artinya belajar secara individual dimana santri berhadapan dengan guru, terjadi interaksi saling mengenal diantara seluruh santri. ${ }^{40}$ diberikan kepada santri-santri yang mengaji al-qur'an, system ini hanya diberikan kepada santri yang membutuhkan perhatian khusus dengan bimbingan sacara individual, serta hal ini merupakan metode paling sulit sebab membutuhkan kesabaran, kedisiplinan, kerajinan dan ketaatan dari sang murid. ${ }^{41}$

\footnotetext{
36 Matsuhu, Dinamika sistem pendidikan pesantren, (Jakarta : INIS, 1994), hal 8,

37 Dikutip dari buku Affandi Mochtar, Membedah Diskursus Pendidikan islam, (Ciputat : Kalima, 2001), 36-37, lebih lengkapnya lihat Masdar Farid F Mas'udi, Pandangan Hidup 'Ulama Indonesia (Ui)' Dalam Literature Kitab Kuning, makalah seminar Nasional tentang pandangan hidup ulama indonesia, LIPI Jakarta, 24-25 februari 1988, 1

38 Imron Arifin, Kepemimpinan kyai kasus Pondok Pesantren Tebuireng, (Malang : kalmiasahada, 1992), 9

39 Affandi Mohtar, Membedah Diskursus pendidikan Islam, (Ciputat: Kalimah, 2001), 81

${ }^{40}$ Affandi Mohtar, Membedah Diskursus pendidikan Islam, (Ciputat: Kalimah, 2001),. 61.

41Zamakhsari Dhofir, Tradisi Pesantren, studi tentang pandangan hidup kiai, (Jakarta : LP3ES, 1994) 28. dan seperti dijelaskan dalam Taklimu Al-Muta'allim syarat bagi santri dalam mencari ilmu yaitu (artinya) :Kecerdasan, semangat dan tekad bulat, kesabaran dalam menuntut ilmu, punyak modal atau kemampuan financial, petunjuk guru dan masa belajar yang lama, dan lihat juga
} 
Metode bandongan, yaitu belajar secara berkelompok yang diikuti oleh seluruh santri. ${ }^{42}$ Metode ini di pesantren sering digunakan ( metode utama) dalam belajar bersama kiai. Setiap murid memperhatikan kitab sendiri dan membuat catatan-catatan (baik arti ataupun keterangan) tentang kata-kata ataupun buah pikiran. ${ }^{33}$ Dan metode halaqah yaitu diskusi untuk memahami isi kitab, bukan untuk mempertanyakan kemungkinan benar salahnya apa apa yang diajarkan dalam kitab, akan tetapi untuk memahami maksud yang dipelajari dari suatu kitab. ${ }^{44}$ Metode ini sering disamakan dengan metode bandongan karena kelompok santri yang belajar dibawah bimbingan kiai/ustadz. ${ }^{45}$ Metode musyawarah yakni santri-kiai belajar bersama dalam bentuk seminar (Tanya jawab), dan santri mempelajari kitab-kitab yang akan dibahas, hampir seluruh menggunakan bahasa arab, dan meruapakan latihan bagi santri untuk memcari argumentasi dalam sumber-sumber kitab-kitab klasik. ${ }^{46}$

\section{Profil singkat Pondok Pesantren Annuqayah,}

disingkat PPA. Kata "Annuqayah" dalam Bahasa Arab berarti: kebersihan, kemurnian dan pilihan. Nama tersebut diambil dari nama sebuah risalah (kitab kecil) karangan Imam Jalaluddin As-Suyuthi judulnya itman ad-dirayah li al-qurra' Annuqayah yang memuat ringkasan pengenalan tentang empat belas (14) disiplin ilmu yang mencakup ilmu-ilmu agama, ilmu-ilmu Arabiyah dan ilmu-ilmu umum yaitu Ilmu Kedokteran dan Ilmu Anatomi. Dengan penamaan tersebut pendiri atau pengasuh PPA berharap (tafaul) agar santri PPA nanti dapat menguasai ilmu yang luas tidak hanya ilmu-ilmu agama dan ilmu-ilmu Arabiyah tetapi juga ilmuilmu umum. Prinsip Epistemologis pada -hakikatnya tidak ada dikotomi ilmu menjadi ilmu "umum" dan ilmu "agama", tetapi semua ilmu itu adalah berasal dari Allah SWT. 47

Kini mengalami perkembangan dan kemajuan yang cukup pesat, khususnya di bidang fisik. Perkembangan dan kemajuan ini berkat partisipasi dan dukungan berbagai pihak antara alumni, wali santri, pemerintah, dan masyarakat. Saat ini Annuqayah mempunyai 25 hektar tanah, berupa pekarangan, tanah

dalam redaksi teks yang berbeda George Makdisi, dalam the rise of Colleges, Institutions Of Learning In Islam And The West (endiburgh university press, 1981), 1.

42 baca, Matsuhu, Dinamika sistem pendidikan pesantren, (Jakarta : INIS, 1994) . 61. Dalam sistem ini semua santri yang hadir mendengarkan seorang guru membaca, menerjemahkan, menerangkan, dan seringkali mengulas buku-buku islam dalam bahasa arab (kitab kuning), lihat juga Zamakhasari Dhofir,.28

43 Perlu diketahui bahwa metode ini hanya ditujukan pada santri yang sudah melewati sistem sorogan, dengan demikian santri dapat mudah memahami yang dibacakan oleh sang kiai .lihat Zamakhsari Dhofir,. .30.

${ }^{44}$ Matsuhu, Dinamika sistem pendidikan pesantren, (Jakarta : INIS, 1994), 61

${ }^{45}$ Lihat Imron Arifin, Kepemimpinan Kiai, Kasus Pondok pesantren Tebu Ireng ,(Malang : kalimasahada, 1993),. 10.

46 Imron Arifin, Kepemimpinan Kiai, Kasus Pondok pesantren Tebu Ireng ,(Malang : kalimasahada, 1993), 31.

${ }^{47}$ Arsip Dukumen Profil pondok pesantren Annuqayah Guluk-guluk Sumenep.(t.th),. lihat Juga, Huub De Jonge, Madura Dalam Empat Zaman: Pedagang, Perkembangan Ekonomi, dan Islam, Suatu studi Antropologi Ekonomi, (Jakarta ; PT. Gramedia, 1989 ), 244. 
pertanian dan 2 hektar tanah tambak pegaraman.48 Dan juga juga memiliki puluhan bangunan dan ratusan ruangan belajar, perkantoran, asrama, masjid, dan mushalla.

Pendiri K.H. M. Syarqawi, beliau berasal dari kota Kudus Jawa Tengah, tepatnya di daerah Sucen, RT 1, RW 1, Kelurahan Kerjasan Kecematan Kota Kudus, kira-kira 450 meter garis lurus ke arah utara dari makam Sunan Kudus. ${ }^{49}$ Beliau menikah dengan perempuan bernama Nyai Hj. Khatijah (istri pertama), janda kiai Gemma, seorang saudagar dari Prenduan, kabupaten Sumenep. setelah beliau belajar (mondok) di Tanah Suci Makkah al-Mukarramah. Pada tahun 1875 M (1293 H), Ia menetap di Prenduan sambil mengajar al-Qur'an dan ilmu agama dari kitab-kitab untuk masyarakat umum, sehingga banyak anggota masyarakat banyak yang mengikuti pengajiannya. Kemudian ia menikah untuk kedua kalinya dengan seorang perempuan di desa Guluk-guluk bernama Mariyah. Dari pernikahan ini dikarunia keturunan putra generasi pengasuh pondok pesantren Annuqayah. 50

Tepat pada tahun 1887 M, yaitu tahun K.H. M. Syarqawi mendirikan sebuah Surau kayu tempat beliau mendidik para santrinya. Bersama K.H. M. Bukhari (putra pertama) tinggal di Guluk-guluk daerah sekitar 8 kilometer sebelah utara Prenduan. Karena desa Prenduan ini kurang kondusif lagi untuk sebuah pesantren yang ramai dan padat penduduk. Langgar yang didirikan oleh K. H. Syarkawi ini di kenal dalem tenga (pada saat ini dijadikan tempat pemakaman keluarga). Dan rumah Qamariyah terletak jauh, sekitar $200 \mathrm{~m}$ kearah Barat Daya dari dalem tenga. Kediaman Nyai Qamariyah inilah yang terkenal dengan sebutan Lubangsa. Hingga akhirnya kediaman itu pondok pesantren Guluk-guluk menjadi sebutan. ${ }^{51}$ pada tahun 1910 M K. H. Syarqawi berpulang ke Rahmatullah. Masa merintis Annuqayah selama 23 tahun. Setelah pendiri meninggal proses pendidikan diganti oleh K.H.M. Bukhari (putra pertama), K.H. Moh. Idris, K.H. Imam Karay, Sumenep. Yang pernah menikah dengan putra kiai Syarqawi Ny. Zubaidah. Meski kegiatan pesantren sama dengan masa pendiri yakni mengajar pengajian dan ilmu keagamaan dalam bentuk wetonan dan kolektif. Dan Ny. Khadijah merintis pengajian al-Qur'an untuk putri-putri masyarakat di sekitar pesantren. Pada tahun 1917 K.H. Ilyas ${ }^{52}$ pulang ke pondok Guluk-Guluk dari Mekkah.

\footnotetext{
48KH.Basith Abdullah Sajjad, Pondok pesantren Annuqayah, epistemology dan Sumbangan fikiran untuk pengembangan keilmuan, (Guluk-guluk: Penerbit PP. Annuqayah, 2007), 3

49 Boklet, Profil Pondok Pesantren Annuqayah Guluk-Guluk Sumenep Madura (Guluk-Guluk : Pusat Data Pondok Pesantren Annuqayah, 2010).

50 Boklet, Profil Pondok Pesantren Annuqayah Guluk-Guluk Sumenep Madura (Guluk-Guluk : Pusat Data Pondok Pesantren Annuqayah, 2010), 4

51Boklet, Profil Pondok Pesantren Annuqayah Guluk-Guluk Sumenep Madura (Guluk-Guluk : Pusat Data Pondok Pesantren Annuqayah, 2010), 5-6

52 Ia merupakan santri kelana, pesantren yang pernah di singgahi untuk belajar ilmu -ilmu dari K.H. R. Khalil Bangkalan, K.H. Hasyim Asy'ari Jombang,
} 
Tepat pada tahun 1923 lima tahun setelah K.H. Ilyas pulang ke GulukGuluk baru kiai menyusul K.H. Abdullah Sajjad ${ }^{53}$ mendirikan pesantren otonom dilingkungan Pondok pesantren guluk sekitar $100 \mathrm{~m}$ dari kediaman asal, sekarang dkenal latee. Ia mengajar ilmu agama dan gramatika bahasa Arab. Pada tahun 1916 pondok pesantren Tebu Ireng Jombang mendirikan Madrasah Salafiyah yang kurikulum yang mengajar ilmu-ilmu umum sedang pesantren-pesantren lainnya masih tabu terhadap pendidikan umum. Pada tahun 1930 Pesantren GulukGuluk, membuka Madrasah Annuqayah ${ }^{54}$ seperti pesentren Tebuireng. Yang di prakarsai oleh K.H. Ilyas dan K.H. Khazin Ilyas. Dengan kurikulum 30 \% umum dan $70 \%$ agama yang mana pelajaran umum hanya sebatas pelengkapan. Sejak tahun 80-an Annuqayah mendirikan yayasan dan sekolah tinggi serta mengupayakan perluasan areal tanah dan melanjutkan pembangunan gedunggedung serta penyempurnaan fasilitas lainnya sampai saat ini. Adapun nama badan hukum Yayasan Annuqayah W.10-Ds.Um.07.01-02/P.A, Wm.06.03/PP.03.2/115/SKP/1999. Lokasi Dusun Guluk-Guluk Tengah, Desa Guluk-Guluk, Kec. Guluk-Guluk, Kab. Sumenep, Jawa Timur.

Kini Kepimpinan di pondok pesantren Annuqayah berada pada Dewan Masyayikh (yang juga sebagai Dewan Pengasuh/Dewan Pembina Yayasan) yang terdiri dari K. H. Ahmad Basyir AS (Ketua merangkap anggota), K. H. A. Warits Ilyas (al-marhum sebagai anggota, kini diganti oleh putranya), K. H. A. Muqsith Idris (anggota), K. H. A. Basith AS (al- marhum anggota kini dignti putranya), K. H. Abbasi Ali (anggota).

Paham yang dianut Aqidah Ahlus Sunnah wal Jamaah, Shariah : Shafi'iyah, Akhlaq-Tasawuf, menganut paham Imam Al-Ghozali dan Imam Junaid AlBaghdadi. Dengan visi menjadi lembaga pendidikan terkemuka dalam melahirkan generasi abdullah yang bertaqwa, tafaqqu $>h$ fiddi $<n$, berilmu luas dan menjadi mund\}irul qau>m.

Kegiatan pertama, Menyelenggarakan pendidikan lewat jalur pendidikan formal dari tingkat TK hingga PT sebagai berikut ${ }^{55}$ : 1. Playgroup, 2. Taman KanakKanak 1 Annuqayah, 3.Taman Kanak-Kanak 2 Annuqayah, 4. MI 1 Annuqayah (Putra, Madrasah ini merupakan satuan pendidikan tertua di Annuqayah - dan mungkin di Madura - berdiri tahun 1933 M. 5. MI 3 Annuqayah (Putri) 6. MTs. 1 Annuqayah (Putra). Membuka kelas khusus kurikulum pesantren, 7. MTs. 1 Annuqayah (Putri). Membuka kelas khusus kurikulum pesantren, 8. MTs. 2 Annuqayah (Putra), 9. MTs. 3 Annuqayah (Putri), 10. MA 1 Annuqayah (Putra). Jurusan: IPS dan IPA, 11. MA 1 Annuqayah (Putri). Jurusan: Keagamaan, IPS, dan IPA , 12. MA Tahfidh Annuqayah (Putra). Jurusan Keagamaan, 13. MA 2 Annuqayah (Putra). Jurusan IPS dan IPA, 14. SMA 1 Annuqayah (Putra). Jurusan IPS dan IPA, 15. SMA 3 Annuqayah (Putri). Jurusan IPS dan IPA, 16.SMK

${ }^{53}$ Adik kandung K.H. Moh. Ilyas setelah pulang dari pondok pesantren KH. Khalil Bangkalan, K.H. Hasyim Asy'ari dan pesantren Panji Sidoarjo

54 Sejak saat itu nama Annuqayah di lekat pondok Guluk -Guluk yang di nisbatkan pada sebuah kitab Imam as-Shuyuti seperti yang dijelaskan pada awal bab ini.

55Boklet, Profil Pondok Pesantren Annuqayah Guluk-Guluk Sumenep Madura (Guluk-Guluk : Pusat Data Pondok Pesantren Annuqayah, 2010), 12. 
Annuqayah (Putra-Putri dengan lokasi yang terpisah). Jurusan: Menejemen Bisnis, Prodi Pemasaran, 17. Institut Ilmu Keislaman (INSTIK, dulu STIK) Annuqayah (Putra-Putri dengan kampus yang terpisah). Berdiri tahun 1984. Jurusan-jurusan: Muamalat, Pendidikan Agama Islam dan Tafsir Hadits . Jurusan-jurusan dalam proses pengajuan ke Kemenag RI: Aqidah, Pendidikan Bahasa Arab, Ahwal Syakhshiyah, pada tahun 2012/2013 bertambah prodi yaitu Hukum Ekonomi Islam dan Ekonomi Islam, dan membuka program Magister PAI konsentrasi Kajian kepesantren, satu-satunya di Indonesia.

Kedua,56 Menyelenggarakan madrasah diniyah klasikal dari tingkat Ula hingga Wustha sebanyak 11 satuan pendidikan. Ketiga, Menyelenggarakan halaqah-halaqah/majlis ta'lim non klasikal di Masjid dan mushalla-mushalla dengan subyek kitab-kitab tauhid/aqidah, syari'ah/fiqih, akhlak-tasawuf dan qawaidul lughah. Keempat, Menyelenggarakan bimbingan qira'atul qur'an secara sorogan kepada para pengasuh, bimbingan qira'atul qur'an bit-taghanni, tahfidul qur'an, bimbingan khusus membaca kitab-kitab turath, batthul masail, kursus Bahasa Arab ashriyyah (kontemporer), ilmu falak dll.

Kelima, Menyelenggarakan pendidikan kepanduan, kesenian, jurnalistik, pendidikan tulis menulis ini berada dibawah naungan pondok masing-masing daerah pondok dan Madarasah atau sekolah dibawah naungan Yayasan Pondok Pesantren Annuqayah dan atas Inisiatif santri membentuk komunitas-komunitas santri, PMR/BSMR, ketrampilan atau kewirausahaan, bela diri, dll. Keenam, Melakukan pengembangan swadaya masyarakat di bidang ekonomi, kesehatan dan lingkungan hidup yang dilakukan baik secara mandiri oleh PPA maupun bersama mitra LSM-LSM dalam maupun luar negeri. LSM-LSM yang pernah menjadi mitra PP. Annuqayah:57

a. Dalam negeri : LP3ES, P3M Jakarta, Bina Desa Jakarta, Bina Swadaya Jakarta, LPTP (Pendiri Bapak Adi Sasono) Jakarta, Dian Desa Yogyakarta, PKBI Jakarta, WALHI Jakarta, Komnas HAM Jakarta, INSIS Yogyakarta, RMI/NU, Yayasan Mandiri Bandung dan Yayasan KEHATI Jakarta

b. Luar Negeri : ACFORT Filipina, CIDA Canada, IDEX Amerika Serikat, NOVIP Belanda, USAID Amerika Serikat, AUSAID Australia, Fridrich Nauman Stiftung Jerman, GTZ Jerman,

c. Penghargaan Tingkat Nasional : Kalpataru 1981, Kategori Penyelamat Lingkungan Hidup.

\section{Sistem Pendidikan di Pondok Pesantren Annuqayah.}

Pada awal berdiri pesantren hanya sebatas mengajar al-qur'an dan ilmu agama yang di ajarkan pada masyarakat sekitar, dengan system sorogan dan

\footnotetext{
56 Boklet, Profil Pondok Pesantren Annuqayah Guluk-Guluk Sumenep Madura (Guluk-Guluk : Pusat Data Pondok Pesantren Annuqayah, 2010),.30

57 Boklet, Profil Pondok Pesantren Annuqayah Guluk-Guluk Sumenep Madura (Guluk-Guluk : Pusat Data Pondok Pesantren Annuqayah, 2010), 7
} 
wetonan. Sebagai lembaga yang pendidikan yang berkembang pesat 58 . Tentu system pendidikan pondok pesantren sudah memperbarui kurikulum pesantren dengan berdirinya Madrasah/sekolah.

Dalam bentuk klasikal. Seperti yang di sebutkan di atas jenis pendidikan formal yang diselenggarakan di pondok pesantren Annuqayah mulai dari taman kanak-kanak hingga perguruan tinggi, baik yang berada di bawah naungan Kementerian Agama ataupun di bawah lingkungan Kementerian Pendidikan Dan Kebudayaan . Dan juga non formal yakni pondok pesantren itu sendiri, dengan mengikuti pengajian kitab kuning, dan kegiatan-kegiatan ubudiyah lainnya. Seperti sholat berjama'ah, membaca Al-Qur'an dan sebagainya selama 24 Jam dalam kehidupan pesantren.

Pondok pesantren Annuqayah adalah pesantren federal terdiri dari atas Pesantren Lubangsa Raya, Pesantren Lubangsa Selatan, Pesantren Nirmala, Pesantren Latee dan daerah lainnya ${ }^{59}$. Dari masing-masing pesantren mempunyai program kegiatan kitab kuning dan kegiatan ubudiyah yang lainnya yang otonom. Jumlah total peserta didik 5.829 santri, terdiri dari 4.546 santri dalam asrama dan 1.283 pelajar/mahasiswa kalong. Dari persebaran santri yang mondok di Pondok Pesantren Annuqayah ini, hampir 85\% adalah santri asli Sumenep dan sisa $15 \%$ adalah santri yang tersebar dari berbagai pelosok Jatim dan daerah lain di Indonesia. Sedangkan santri yang bermukim di pesantren $80 \%$ sedangkan sisanya $20 \%$ adalah santri kalong, mayoritas adalah Mahasiswa dan sebagian di Madarasah atau sekolah ${ }^{60}$.

Kehidupan santri sehari-hari dalam pesantren, dapat diilustrasikan : para santri mengurus segala kebutuhan diri sendiri, baik itu kebutuhan pribadi dalam pondok, seperti memasak dan sebagian kecil membeli dikantin, mencuci pakaian, kegiatan pengembangan potensi diri di biar seluas-luasnya dengan disesuaiakan norma dan peraturan pondok pesantren, termasuk kegiatan tulis menulis, olahraga, sanggar, dan lain-lain.

Sedangkan madrasah/sekolah/perguruan tinggi di Annuqayah adalah berbentuk klasikal, seperti lembaga pendidikan modern pada umumnya. Dengan pembagian kurikulum disesuaikan dengan system pendidikan nasional baik, di bawah naungan kementerian pendidikan dan kebudayaan (KEMENDIKBUD) dan ataupun kementerian Agama (KEMENNAG). Tentu hal ini merupakan proses yang panjang bagi pondok pesantren Annuqayah. ${ }^{61}$

58 Arsip Dukumen Profil pondok pesantren Annuqayah Guluk-guluk Sumenep.(t.th), ${ }^{58 \mathrm{KH}}$.Basith Abdullah Sajjad, Pondok pesantren Annuqayah, epistemology dan Sumbangan fikiran untuk pengembangan keilmuan, (Guluk-guluk : Penerbit PP. Annuqayah, 2007), 3

59 Boklet, Profil Pondok Pesantren Annuqayah Guluk-Guluk Sumenep Madura (Guluk-Guluk : Pusat Data Pondok Pesantren Annuqayah, 2010), 28, seperti yang terlihat di daftar daerah pesantren terdapat 27 Daerah beserta Jumlah santri-santriwati, terupdate tahun 2010.

60 Mastuhu, Dinamika Sistem Pendidikan Pesantren Suatu kajian tentang Unsur dan Nilai Sistem pendidikan pesantren, (Jakarta: INIS, 1994 ), 94

${ }^{61}$ Boklet, Profil Pondok Pesantren Annuqayah Guluk-Guluk Sumenep Madura (Guluk-Guluk : Pusat Data Pondok Pesantren Annuqayah, 2010), 3 


\section{Penutup}

Tradisi akademik santri di pesantren, merupakan satu bentuk proses pembelajaran yang tuntas, yang dapat menampilkan satu sosok lulusan pesantren yang berwawasan luas, berkepribadian matang, dan berkemampuan tinggi dalam melakukan rekayasa social. Pengajaran kitab-kitab kuning tersebut oleh santri kiai dilakukan berbentuk sorogan, bandungan atau weton, halaqah dan kelas musyawarah. Pondok Pesantren Annuqayah diambil kitab itman ad-dirayah li alqurra' Annuqayah karya Imam Jalaluddn As-Suyuthi yang memuat ringkasan pengenalan tentang empat belas disiplin ilmu yang mencakup ilmu-ilmu agama, ilmu-ilmu Arabiyah dan ilmu-ilmu umum yaitu Ilmu Kedokteran dan Ilmu Anatomi. Sedangkan sistem pendidikan di PP Annuqayah yaitu sistem shalaf (tradisional) dan khalaf (Modern, klasikal). System shalaf ini dalam pondok pesantren di Annuqayah digunakan dalam pondok pesantren itu sendiri, baik Sorogan, weton, bandungan. Sistem khalaf dalam Pondok Pesantren Annuqayah dalam perkembangannya, ada tiga sistem yang diterapakan di Pondok Pesantren yaitu Sistem Klasikal, sistem kursus-kursus, pendidikan dan latihan.

\section{DAFTAR PUSTAKA}

Anam, Chairul, Pertumbuhan dan perkembangan NU, (Surabaya: Duta Aksara, 2010)

Arifin, Imron Kepemimpinan Kiai, Kasus Pondok Pesantren Tebuireng, (Malang : Kalimasahada Press, 1993)

Arsip Dukumen Profil pondok pesantren Annuqayah Guluk-guluk Sumenep.(t.th),

Asroha, Hanun Pelembagaan Pesantren, Asal Usul dan Perkembangan pesantren di Jawa (Jakarta DEPAG RI, 2004)

Baso, Ahmad, Pesantren Studies 2a, Buku II : Kosmopolitanisme Peradaban Kaum Santri di Masa Kolonial, Juz pertama : pesantren, Jaringan pengetahuan dan Karakter Kosmopolitan-kebangsaannya, (Jakarta : Pustaka afid)

Boklet, Profil Pondok Pesantren Annuqayah Guluk-Guluk Sumenep Madura (GulukGuluk : Pusat Data Pondok Pesantren Annuqayah, 2010).

Bruinessen, Martin van, kitab kuning, pesantren dan tarekat, (Yogyakarta : Madianah, 2012)

Dhofir, Zamakhsari Tradisi Pesantren, studi tentang pandangan hidup kiai, (Jakarta : LP3ES, 1994)

Jonge, Huub De, Madura Dalam Empat Zaman: Pedagang, Perkembangan Ekonomi, dan Islam, Suatu studi Antropologi Ekonomi, (Jakarta ; PT. Gramedia, 1989 ).

Madjid, Nur Khalis Pola pergaulan dalam pesantren, dalam buku Bilik-Bilik Pesantren, (Jakarta : Dian Rakyat) 
Bilik-Bilik Pesantren (Jakarta : Dian Rakyat, )

Makdisi, George, The Rise of Colleges, Institutions Of Learning In Islam And The West (endiburgh university press, 1981)

Mastuhu, Dinamika Sistem Pendidikan Pesantren Suatu kajian tentang Unsur dan Nilai Sistem pendidikan pesantren, (Jakarta: INIS, 1994 ).

Mohtar, Affandi Membedah Diskursus Pendidikan Islam,(Ciputat: Kalimah, 2001)

Pingeaud, literature of Java, vol. 2 dan 3 serta Voorhoeve, handlist.

Prasojo, Soedjoko, Profil Pesantren (Jakarta : LP3ES, 1978 )

Sajjad, Basith Abdullah, Pondok Pesantren Annuqayah, Epistemology dan Sumbangan Fikiran untuk Pengembangan Keilmuan, (Guluk-guluk : Penerbit PP. Annuqayah, 2007)

Siraj, Said Agil, Tasawwuf Sebagai Kritik Sosial, (Jakarta. LTN,2012)

Wahid, Abdurahman, Menggerakkan Tradisi, (Yogyakarta: LKIS, 2010) , Bunga Rampai Pesantren, (LP3ES, Jakarta, 1982) 